\title{
Ispinesib Mesylate
}

National Cancer Institute

\section{Source}

National Cancer Institute. Ispinesib Mesylate. NCI Thesaurus. Code C77518.

The mesylate salt form of ispinesib, a synthetic small molecule, derived from

quinazolinone, and kinesin spindle protein (KSP) inhibitor, with antineoplastic activity.

Ispinesib selectively inhibits KSP and prevents its binding to microtubules, resulting in

inhibition of mitotic spindle assembly, induction of cell cycle arrest during the M-phase,

and cell death in tumor cells that are actively dividing. 